\title{
Polyol dehydrogenases in axenic mycelia of the wheat stem rust fungus Puccinia graminis f. sp. tritici
}

\author{
Donald J. Maclean \\ Department of Biochemistry, The University of Queensland, St Lucia, Queensland 4072, Australia
}

(Received 15 May 1990; revised 10 July 1990; accepted 13 July 1990)

\begin{abstract}
Activities of the polyol dehydrogenases of Puccinia graminis $f$. sp. tritici were surveyed by measuring polyoldependent rates of reduction of $\mathrm{NAD}^{+}$and NADP ${ }^{+}$in cell-free extracts of axenically-grown mycelia. Seven of the eight polyols tested caused NADP ${ }^{+}$reduction, with highest activity for D-glucitol, followed by L-arabitol, xylitol, erythritol, galactitol and ribitol, and low activity with D-arabitol; only D-mannitol failed to support activity. Inactivation rates were consistent with at least three separate enzymes, specific for D-glucitol, xylitol and L-arabitol respectively, with apparent $K_{\mathrm{m}}$ values of $170-198 \mathrm{mM}$ for xylitol and D-glucitol $\left(K_{\mathrm{m}}\right.$ for NADP+ 36-55 $\mu \mathrm{M})$, and $34 \mathrm{mM}$ for L-arabitol $\left(K_{\mathrm{m}}\right.$ for NADP $\left.+1.2 \mu \mathrm{M}\right)$. The NADP ${ }^{+}$-dependent activities were almost completely inhibited by 2 mM-dithiothreitol, in contrast to the $\mathrm{NAD}^{+}$-dependent activities, which were stimulated. $\mathrm{NAD}^{+}$-dependent activity was highest with D-mannitol, followed by successively lower activities with D-arabitol, xylitol and D-glucitol, with no activity with any of the other polyols; each of the four active polyols appeared to be oxidized by a different enzyme. All four $\mathrm{NAD}^{+}$-dependent activities were rapidly lost after Sephadex treatment of crude extracts.
\end{abstract}

\section{Introduction}

Compared to most fungi, the wheat stem rust fungus Puccinia graminis f. sp. tritici accumulates a particularly diverse collection of sugars and sugar alcohols (polyols) within its mycelia and spores (Maclean, 1982; Maclean \& Scott, 1976; Lewis \& Smith, 1967; Pfyffer et al., 1986). When grown in axenic culture on the surface of a glucosecontaining medium, mycelia of $P$. graminis contain relatively high concentrations of the acyclic hexitols D-glucitol and D-mannitol, the disaccharide trehalose, the pentitols ribitol and D-arabitol, and the hexoses glucose and fructose, together with traces of the pentitol xylitol, the tetritol erythritol, and the cyclic hexitol inositol (Maclean \& Scott, 1976). The acyclic polyols also accumulate in mycelia grown in liquid suspension culture, but at lower concentrations on a dry weight basis (Manners et al., 1982; unpublished data of D. J. Maclean). Because uredospores and their sporelings do not accumulate D-glucitol or ribitol (Maclean \& Scott, 1976), surface-grown axenic mycelia were chosen as the best material for a survey of the polyol-metabolizing enzymes of $P$. graminis.

The objective of the present investigation was to survey the number of enzymes in cell-free extracts of $P$. graminis capable of catalysing the oxidation of free polyols, and to examine some of their characteristics. The experimental approach was to measure polyoldependent $\mathrm{NAD}(\mathrm{P})^{+}$-reducing activities for a variety of polyols (including those previously identified in $P$. graminis), using crude and Sephadex-treated extracts of mycelia as source of enzyme. An unpublished description of much of this work was reported previously (Maclean, 1971), and formed the basis for a subsequent investigation of the polyol dehydrogenases present in crude extracts of axenically-grown mycelia of the flax rust fungus, Melampsora lini (Clancy \& Coffey, 1980).

\section{Methods}

Sources of chemicals. All polyols and nicotinamide nucleotides used as substrates for enzyme assays were obtained from Sigma or BDH. The high $K_{\mathrm{m}}$ values for polyol dehydrogenases (see Results) necessitated a high concentration of substrate (100 mM-polyol) for routine assays of activity (Table 1). Because high substrate concentrations in assays might introduce contaminants which would also react with nicotinamide nucleotides to give side-reactions other than polyol dehydrogenase activity, all of the polyols tested as substrates were recrystallized before use in assays, using the solvent systems suggested by Barnett (1968) with omission of the pyridine step for D-glucitol. After recrystallization, polyols were dried by alternate treatments in an oven $\left(50^{\circ} \mathrm{C}\right)$ and a low vacuum desiccator, to remove traces of solvent (e.g. ethanol) which might give side-reactions in enzyme assays. 
Growth of the fungus. Strain V1B, originally isolated from race 126-ANZ-5,6,7,11 of Puccinia graminis f. sp. tritici (Maclean \& Scott, 1970; Maclean, 1974), was grown on the peptone/glucose medium described by Maclean \& Scott (1976). Mycelia were lightly fragmented in liquid medium in a rotary-blade homogenizer, and inoculated on cellulose film (Cellophane; cf. Maclean, 1974) overlaid on medium solidified with $1 \%(\mathrm{w} / \mathrm{v}$ ) agar (Difco) in $14 \mathrm{~cm}$ diameter glass Petri dishes; after $\sim 30 \mathrm{~d}$ growth at $23-25^{\circ} \mathrm{C}$ in the dark, mycelia $(3-6 \mathrm{~g}$ fresh weight) were peeled from the surface of each dish, then blotted with filter paper before use.

Preparation of acetone powders. Surface-grown mycelia were homogenized with $\sim 10$ vols chilled $\left(-20^{\circ} \mathrm{C}\right)$ acetone in a Waring blender, washed with further chilled acetone and sucked dry in a Buchner funnel, then dried and stored in vacuo at $4{ }^{\circ} \mathrm{C}$ over anhydrous calcium chloride and concentrated sulphuric acid. Crude extracts of both fresh mycelia and acetone powder gave similar assay results (see Table 1), and the original activity was retained with most polyols after dry storage of acetone powders at $0{ }^{\circ} \mathrm{C}$ for up to 4 months.

Preparation of crude enzyme extract. Surface-grown mycelia $(1 \mathrm{~g}$ in $15 \mathrm{ml})$ or acetone powder $\left(50 \mathrm{mg} \mathrm{ml}^{-1}\right)$ were homogenized at $4{ }^{\circ} \mathrm{C}$ in a glass Ten Broeck hand homogenizer in $100 \mathrm{~mm}$-Tris/ $\mathrm{HCl} \mathrm{pH} 7 \cdot 4$ containing $2 \mathrm{~mm}$-EDTA, left at $4{ }^{\circ} \mathrm{C}$ for $30 \mathrm{~min}$, then centrifuged at $30000 \mathrm{~g}$ for $30 \mathrm{~min}$ to provide the supernatant (crude extract). When required, $5 \mathrm{ml}$ supernatant was passed through a $2.2 \mathrm{~cm}$ diameter $\times 15 \mathrm{~cm}$ column of Sephadex G25 fine (Pharmacia) equilibrated with homogenization buffer, and the peak $5 \mathrm{ml}$ of the void was retained as 'Sephadex-treated extract'. Protein was determined by the Lowry method.

Assays of polyol dehydrogenase activity. Polyol dehydrogenase activity was determined by recording the rate of $\mathrm{NAD}^{+}$or $\mathrm{NADP}^{+}$reduction (increase in $A_{340}$ in a water-jacketed cell holder at $23^{\circ} \mathrm{C}$ ); for most assays a Gilford model 240 spectrophotometer linked to a Rikadenki model B-140 chart recorder set to a full-scale expansion of 0.2 absorbance units was used. The standard assay mixture contained (in a $1 \mathrm{ml}$ silica cuvette): $0.2 \mathrm{mM}-\mathrm{NAD}^{+}$or $\mathrm{NADP}^{+}$as specified, $100 \mathrm{~mm}$-polyol as specified, $100 \mathrm{mM}-\mathrm{Tris} / \mathrm{HCl} \mathrm{pH} 8.5$, in a final volume of $1 \mathrm{ml}$ containing 0.05 or $0.1 \mathrm{ml}$ enzyme extract (equivalent to $50-100 \mu \mathrm{g}$ protein); assays were started by the addition of enzyme (other components if required were included prior to starting the assay). If necessary, enzyme preparations were diluted so that reaction rates were less than 0.2 absorbance units per $5 \mathrm{~min}$; except for some of the data in Tables 1 and 2 (see Results), reaction rates were linear for at least 4-5 min after addition of the enzyme. The results of replicate assays conducted consecutively were generally within $5 \%$ of each other, but because extracts lost activity rapidly after Sephadex treatment (e.g. Table 2), most assays in a comparative series were only done once to minimize differences due to enzyme inactivation. Results are presented

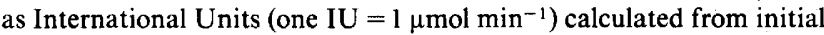
rates using a molar absorption coefficient of $6220 \mathrm{M}^{-1} \mathrm{~cm}^{-1}$ at $340 \mathrm{~nm}$ for NADH and NADPH.

Determination of $K_{\mathrm{m}}$ values. Values for $\mathrm{NADP}^{+}$-dependent polyol dehydrogenases were obtained by first determining apparent $K_{\mathrm{m}}$ values for NADP+ using $200 \mathrm{~mm}$-polyol (non-saturating except for L-arabitol) over the range 0.0025-1.6 mM-NADP+, yielding $K_{\mathrm{m}}$ values of $0.055 \mathrm{mM}$ or less for NADP+ (Table 4). This enabled selection of a saturating concentration of NADP+ $(0.8 \mathrm{mM})$ for determination of the $K_{\mathrm{m}}$ for polyols (assayed at 50,100,200, 400 and $800 \mathrm{~mm}$-polyol). Apparent $K_{\mathrm{m}}$ values for $\mathrm{NAD}^{+}$-dependent xylitol dehydrogenase were determined in the presence of $2 \mathrm{mM}$-dithiothreitol (DTT) over the range $0.2-1.6 \mathrm{~mm}$ $\mathrm{NAD}^{+}$at $200 \mathrm{mM}-\mathrm{xylitol}$, and 100,200 and $400 \mathrm{mM}-\mathrm{xylitol}$ at $0.4 \mathrm{mM}-\mathrm{NAD}^{+} . K_{\mathrm{m}}$ values and standard deviations were calculated by a least-squares method using computer program DNRP53 supplied by Dr R. G. Duggleby (Duggleby, 1984).

\section{Results}

Detection of $N A D(P)^{+}$-dependent polyol dehydrogenases in crude extracts

In initial experiments, polyol dehydrogenase activities were assayed in crude extracts prepared from a number of different biological sources of $\boldsymbol{P}$. graminis (Table 1). Polyol dehydrogenase activities, detected as significant polyol-dependent increases in the endogenous rate of $\mathrm{NAD}(\mathrm{P})^{+}$reduction, were observed in extracts of rustinfected wheat, axenic mycelia and germinated uredospores, but not in extracts of non-infected wheat. NAD ${ }^{+}$ dependent activities were observed with D-mannitol, D-arabitol and xylitol; $\mathrm{NADP}^{+}$-dependent activities were observed for D-glucitol, xylitol, L-arabitol and ribitol (germinated uredospores gave relatively low rates for $\mathrm{NADP}^{+}$with a broad spectrum of polyols). Axenically-grown mycelium was used in all further work as it was the most active and abundant source of enzyme; for convenience, bulked mycelia were converted to an acetone powder to provide a constant source of enzyme. Table 1 shows that activities in extracts of acetone powders were very similar to those in extracts of freshlyharvested mycelium when expressed on the basis of equivalent fresh weight, although $\mathrm{NAD}^{+}$-dependent D-arabitol dehydrogenase was apparently partially inactivated by the acetone treatment; however, this difference may have been intrinsic to the different batches of axenic mycelia from which the two enzyme preparations described in Table 1 were prepared.

In experiments using crude extracts of mycelia as enzyme source, some polyols (e.g. erythritol) depressed endogenous rates (see Table 1), raising the possibility that endogenous rates might mask polyol-dependent activities with some polyols. Furthermore, assays of polyol dehydrogenase activity in crude extracts which gave a high endogenous rate (e.g. the extracts of axenic mycelia in Table 1) frequently lost linearity 2-3 min after starting the reaction, possibly as a consequence of the exhaustion of (unknown) endogenous substrates for $\mathrm{NAD}(\mathrm{P})^{+}$-dependent enzymes other than the particular polyol dehydrogenase under investigation. Although it is common to assay polyol dehydrogenase activities in crude extracts and to present results corrected for endogenous rates (e.g. Chiang \& Knight, 1961; Adomako et al., 1972; Clancy \& Coffey, 1980), it was decided to avoid the complication of unknown sidereactions, and enzyme preparations were cleaned up for all further work in the present investigation. Passage of crude extract through a Sephadex G25 gel filtration column virtually eliminated endogenous rates (Table 2 ), but specific activities in the resulting extract were considerably lower, and the activities more labile, 
Table 1. Polyol-dependent $N A D(P)^{+}$-reducing activities in crude extracts of $P$. graminis obtained from different sources

\begin{tabular}{|c|c|c|c|c|c|}
\hline \multirow[b]{3}{*}{ Substrate } & \multicolumn{5}{|c|}{$10^{2} \times$ Enzyme activity [IU (g fresh wt $\left.)^{-1}\right]$} \\
\hline & \multicolumn{2}{|c|}{ Wheat } & \multicolumn{2}{|c|}{ Axenic mycelia } & \multirow{2}{*}{$\begin{array}{c}\text { Germinated } \\
\text { uredo- } \\
\text { spores* }\end{array}$} \\
\hline & $\begin{array}{c}\text { Non- } \\
\text { infected* }\end{array}$ & $\begin{array}{c}\text { Rust- } \\
\text { infected* }\end{array}$ & $\begin{array}{c}\text { Freshly } \\
\text { harvested }\end{array}$ & $\begin{array}{l}\text { Acetone } \\
\text { powder }\end{array}$ & \\
\hline \multicolumn{6}{|c|}{ (a) $N A D^{+}$reduction } \\
\hline D-Glucitol & 0 & 1 & 0 & - & 3 \\
\hline D-Mannitol & 0 & 9 & 31 & 44 & 37 \\
\hline Galactitol & 0 & 0 & - & -- & 0 \\
\hline D-Arabitol & 0 & 22 & 40 & 14 & 36 \\
\hline L-Arabitol & 0 & 0 & 0 & - & 0 \\
\hline Xylitol & 0 & 2 & 13 & 13 & 9 \\
\hline Ribitol & 1 & 0 & 0 & - & 0 \\
\hline Erythritol & $(-2)$ & 0 & $(-4)$ & - & 0 \\
\hline (Endogenous) $\dagger$ & 0 & 0 & 17 & 13 & 0 \\
\hline \multicolumn{6}{|c|}{ (b) $N A D P^{+}$reduction } \\
\hline D-Glucitol & 0 & 12 & 25 & 31 & 5 \\
\hline D-Mannitol & 0 & $(-1)$ & 1 & - & 3 \\
\hline Galactitol & $\mathbf{0}$ & - & - & - & 0 \\
\hline D-Arabitol & 0 & $(-6)$ & 2 & - & 6 \\
\hline L-Arabitol & 0 & - & 10 & -. & 1 \\
\hline Xylitol & 0 & 4 & 17 & 20 & 5 \\
\hline Ribitol & $(-1)$ & - & 8 & - & 2 \\
\hline Erythritol & 1 & -- & $(-3)$ & - & - \\
\hline (Endogenous)† & 0 & 32 & 25 & 31 & 4 \\
\hline
\end{tabular}

- , Not tested.

* Non-infected wheat (first leaves of var. W2691) $8 \mathrm{~d}$ after sowing, rust-infected wheat (heavily infected with race 126-ANZ-5,6,7,11, inoculated $7 \mathrm{~d}$ after sowing and harvested $7 \mathrm{~d}$ after pustule opening), and germinated uredospores (race 126-ANZ-5,6,7,11) were prepared as described by Maclean \& Scott (1976).

$\dagger$ Endogenous rate $=$ activity in absence of polyol; other rates are presented as total activity minus endogenous rate.

especially for the $\mathrm{NAD}^{+}$-dependent reactions, which lost most of the initial activity after cold storage for $24 \mathrm{~h}$. In further experiments, therefore, all $\mathrm{NAD}^{+}$-dependent activities were assayed within $4 \mathrm{~h}$ of extraction, and $\mathrm{NADP}^{+}$-dependent activities within $8 \mathrm{~h}$.

Using Sephadex-treated extracts of acetone powders of axenic mycelia as source of enzyme, eight polyols were compared as substrate. In a typical experiment (Table 3 ), $\mathrm{NAD}^{+}$-dependent activity was highest with $\mathrm{D}$-mannitol, followed by successively lower activities with D-arabitol, xylitol and D-glucitol (the low NAD ${ }^{+}$-dependent glucitol activity was presumably masked by the endogenous rate when using crude extracts: cf. Table 1). Insignificant $\mathrm{NAD}^{+}$-dependent activity was detected using erythritol, $\mathrm{L}$-arabitol, ribitol or galactitol as substrate. In contrast, seven of the eight polyols tested supported NADP ${ }^{+}$ dependent activity, with highest activity for D-glucitol followed by L-arabitol, xylitol, erythritol, galactitol, ribitol, and low activity with D-arabitol; only D-mannitol failed to support activity.
Kinetic and other characteristics of selected polyol dehydrogenases

Selected compounds were tested for their effect on polyol dehydrogenase activity. The presence of 1-2 mM-EDTA in the extraction and gel filtration buffers improved enzyme stability on storage, without inhibiting activity with any polyol (data not presented), indicating that loosely-bound heavy metal cofactors were not required for activity. Whereas the $\mathrm{NAD}^{+}$-dependent polyol dehydrogenase activities were stimulated by the addition of 2 mM-DTT to assay mixtures, the $\mathrm{NADP}^{+}$-dependent activities were almost completely abolished by DTT for all polyols tested, with inhibition ranging from 96 to $100 \%$ in different experiments (Table 3). Other thiols were less inhibitory, with $2 \mathrm{~mm}$-mercaptoethanol inhibiting $\mathrm{NADP}^{+}$-dependent reaction rates by $21-41 \%$, and 2 mM-cysteine inhibiting rates by $0-9 \%$ (data not presented).

Apparent $K_{\mathrm{m}}$ values for the most active $\mathrm{NADP}^{+-}$ 
Table 2. Effect of storage on activity of selected polyol dehydrogenases in crude and Sephadex-treated extracts of axenic mycelia of $P$. graminis

Extracts of freshly-harvested mycelia were used. Fresh extracts were assayed within $4 \mathrm{~h}$ of homogenization; stored extracts were re-assayed after $24 \mathrm{~h}$ on ice.

\begin{tabular}{|c|c|c|c|c|}
\hline \multirow[b]{3}{*}{ Substrate } & \multicolumn{4}{|c|}{$10^{4} \times$ Specific activity $\left[\mathrm{IU}(\mathrm{mg} \text { protein })^{-1}\right]$} \\
\hline & \multicolumn{2}{|c|}{$\begin{array}{l}\text { Crude } \\
\text { extract }\end{array}$} & \multicolumn{2}{|c|}{$\begin{array}{c}\text { After } \\
\text { Sephadex } \\
\text { treatment }\end{array}$} \\
\hline & Fresh & $\begin{array}{c}\text { After } \\
24 \mathrm{~h}\end{array}$ & Fresh & $\begin{array}{c}\text { After } \\
24 \mathrm{~h}\end{array}$ \\
\hline \multicolumn{5}{|c|}{ (a) $\mathrm{NAD}^{+}$reduction } \\
\hline D-Mannitol & 294 & 277 & 89 & $\begin{array}{r}5 \\
15\end{array}$ \\
\hline D-Arabitol & 380 & 209 & $\begin{array}{l}82 \\
35\end{array}$ & 15 \\
\hline Xylitol & 117 & 204 & 35 & \\
\hline (Endogenous) $^{*}$ & 154 & 52 & 5 & 0 \\
\hline \multicolumn{5}{|c|}{ (b) $N A D P^{+}$reduction } \\
\hline D-Glucitol & 232 & 137 & 179 & 97 \\
\hline L-Arabitol & 84 & 72 & - & 67 \\
\hline Xylitol & 162 & 164 & 89 & 35 \\
\hline (Endogenous)* & 242 & 230 & 0 & 5 \\
\hline
\end{tabular}

- , Not tested.

* Endogenous rate = activity in absence of polyol; other rates are presented as total activity minus endogenous rate.

dependent dehydrogenases in extracts of axenic mycelia are presented in Table 4. The $K_{\mathrm{m}}$ values for D-glucitol (198 $\mathrm{mm}$ ) and xylitol (170 $\mathrm{mM})$ were high, consistent with values observed for polyol dehydrogenases in some fungi (e.g. $240 \mathrm{mM}$ for D-mannitol with an $\mathrm{NAD}^{+}$-dependent mannitol dehydrogenase in Chaetomium globosum; Adomako et al., 1972), but not others (e.g. $16 \mathrm{~mm}$ for D-mannitol with an NADP ${ }^{+}$-specific mannitol dehydrogenase in Agaricus bisporus; Morton et al., 1985). A substantially lower $K_{\mathrm{m}}$ of $34 \mathrm{~mm}$ was found for L-arabitol, an apparently non-physiological polyol in $P$. graminis (the $K_{\mathrm{m}}$ for $\mathrm{NADP}^{+}$was also an order of magnitude lower than for D-glucitol and xylitol).

The only $\mathrm{NAD}^{+}$-dependent enzyme subjected to kinetic analysis was xylitol dehydrogenase, which was stabilized by DTT (see below); the activity of the other $\mathrm{NAD}^{+}$-dependent polyol dehydrogenases decayed too rapidly after Sephadex treatment to obtain reliable data. In the presence of $2 \mathrm{~mm}$-DTT, and using substrate concentrations similar to those used for the NADP+. dependent enzymes, the apparent $K_{\mathrm{m}}$ values of the $\mathrm{NAD}^{+}$-dependent xylitol dehydrogenase were $216 \mathrm{mM}$ (SD $\pm 25 \%$ ) for xylitol (in the presence of 0.4 mM-NAD ${ }^{+}$), and $0.67 \mathrm{mM}$ (SD $\pm 13 \%$ ) for $\mathrm{NAD}^{+}$(in the presence of $200 \mathrm{mM}$-xylitol). The apparent $K_{\mathrm{m}}$ for xylitol was comparable to that for the $\mathrm{NADP}^{+}$-dependent enzyme
Table 3. Effect of DTT on polyol dehydrogenase activities in Sephadex-treated extracts of acetone powder of

$$
P \text {. graminis }
$$

Values in parentheses were obtained with 2 mM-DTT in the assay mixture. Endogenous rates were zero.

\begin{tabular}{|c|c|c|}
\hline \multirow[b]{2}{*}{ Substrate } & \multicolumn{2}{|c|}{$10^{4} \times$ Specific activity $\left[\mathrm{IU}(\mathrm{mg} \text { protein })^{-1}\right]$} \\
\hline & $\mathrm{NAD}^{+}$reduction & $\mathrm{NADP}^{+}$reduction \\
\hline D-Glucitol & $8 \quad(8)$ & $217(0)$ \\
\hline D-Mannitol & $90(102)$ & $0(0)$ \\
\hline Galactitol & $\begin{array}{ll}0 & (0)\end{array}$ & $42(0)$ \\
\hline D-Arabitol & $52 \quad(53)$ & $5(0)$ \\
\hline L-Arabitol & $0 \quad(0)$ & $100(3)$ \\
\hline Xylitol & $25 \quad(37)$ & $89(3)$ \\
\hline Ribitol & $0 \quad(0)$ & $24(0)$ \\
\hline Erythritol & $0 \quad(0)$ & $52(0)$ \\
\hline
\end{tabular}

Table 4. Apparent $K_{\mathrm{m}}$ values for $N A D P^{+}$-dependent polyol dehydrogenases in axenic mycelia of $P$. graminis

Enzyme source as in Table 3, using the co-substrate concentrations indicated (percentage standard deviation in parentheses).

\begin{tabular}{lcc}
\hline \hline Polyol & $\begin{array}{c}\boldsymbol{K}_{\mathrm{m}} \text { for polyol } \\
\text { at } 0.8 \mathrm{mM}-\mathrm{NADP}^{+}\end{array}$ & $\begin{array}{c}\boldsymbol{K}_{\mathrm{m}} \text { for NADP+ } \\
\text { at } 200 \mathrm{mM} \text {-polyol }\end{array}$ \\
\hline D-Glucitol & $198 \mathrm{mM}( \pm 7 \%)$ & $0.036 \mathrm{mM}( \pm 13 \%)$ \\
Xylitol & $170 \mathrm{mM}( \pm 8 \%)$ & $0.055 \mathrm{mM}( \pm 4 \%)$ \\
L-Arabitol & $34 \mathrm{mM}( \pm 13 \%)$ & $0.0012 \mathrm{mM}( \pm 8 \%)$ \\
\hline \hline
\end{tabular}

(cf. Table 4); however, the value for $\mathrm{NAD}^{+}$was more than an order of magnitude higher.

\section{Number of distinct activities in enzyme preparations}

To investigate whether the dehydrogenase activities with different polyols were due to a few enzymes with broad substrate specificity, or to many enzymes with narrow substrate specificity, extracts of axenically-grown mycelia were subjected to partial inactivation by heat shock or cold storage. Different inactivation rates of $\mathrm{NADP}^{+}$-dependent reactions (Table 5) were consistent with at least three different enzymes being present, with substrate specificities for (i) xylitol, (ii) D-glucitol and ribitol, and (iii) L-arabitol, erythritol and galactitol. This interpretation is supported by other work such as that of Hollmann \& Latterman (1969), who used hot and cold inactivation to demonstrate that 250 -fold purified preparations of an $\mathrm{NAD}^{+}$-specific polyol dehydrogenase from sheep seminal vesicles consisted of two enzymes specific for D-glucitol and L-arabitol; similarly, Isenberg \& Niederpruem (1967) used hot and cold inactivation to demonstrate that crude extracts of Schizophyllum commune contained more than one $\mathrm{NAD}^{+}$-specific polyol dehydrogenase, a result confirmed by DEAE-cellulose chromatography. An alternative explanation is that a 
Table 5. Stability to heat and cold of $N A D P^{+}$-dependent polyol dehydrogenase activities in extracts of $P$. graminis

Enzyme extracts were prepared as described in Table 3.

\begin{tabular}{|c|c|c|c|c|c|c|}
\hline \multirow[b]{3}{*}{ Substrate } & \multicolumn{6}{|c|}{ Activity as percentage of initial rate } \\
\hline & \multicolumn{2}{|c|}{ Decay at $0^{\circ} \mathrm{C}$} & \multicolumn{4}{|c|}{ Heat treatments* } \\
\hline & $24 \mathrm{~h}$ & $32 \mathrm{~h}$ & (a) & (b) & (c) & (d) \\
\hline Xylitol & 64 & 40 & 60 & 40 & 27 & 16 \\
\hline D-Glucitol & 75 & 59 & 46 & 21 & 11 & 0 \\
\hline Ribitol & - & - & 50 & 23 & 11 & 0 \\
\hline L-Arabitol & 87 & 81 & 34 & 0 & 0 & \\
\hline Erythritol & - & - & 35 & 9 & 0 & $\mathbf{0}$ \\
\hline Galactitol & - & - & 36 & 7 & 0 & 0 \\
\hline
\end{tabular}

- , Not tested.

* $(a),(b)$ and $(c)$ represent successive treatments at $50^{\circ} \mathrm{C}$ for $35 \mathrm{~s} ;(d)$ represents treatment at $50{ }^{\circ} \mathrm{C}$ for $10 \mathrm{~min}$.

Table 6. Relative activities of $\mathrm{NAD}^{+}$-dependent polyol dehydrogenases from different sources of P. graminis

\begin{tabular}{|c|c|c|c|c|}
\hline \multirow[b]{2}{*}{ Substrate } & \multicolumn{4}{|c|}{$\begin{array}{l}\text { Activity as percentage of the D-mannitol activity } \\
\text { of the respective source }\end{array}$} \\
\hline & $\begin{array}{l}\text { Rust- } \\
\text { infected } \\
\text { wheat* }\end{array}$ & $\begin{array}{l}\text { Germinated } \\
\text { uredospores* }\end{array}$ & $\begin{array}{c}\text { Axenic } \\
\text { mycelia } \\
\text { I } \dagger\end{array}$ & $\begin{array}{c}\text { Axenic } \\
\text { mycelia } \\
\text { IIt }\end{array}$ \\
\hline D-Arabitol & 244 & 97 & 58 & 18 \\
\hline D-Glucitol & 5 & 7 & 10 & 13 \\
\hline
\end{tabular}

single or few enzyme(s) of broad substrate specificity underwent conformational changes during the various treatments, resulting in changes in relative activities towards different polyols; such an explanation is considered less likely, as I am unaware of any reports in the literature of differential inactivation towards different polyols of a purified polyol dehydrogenase.

For the $\mathrm{NAD}^{+}$-dependent dehydrogenases, relative activities towards D-mannitol, D-arabitol and D-glucitol varied considerably in extracts prepared from infected wheat, germinated uredospores, and different samples of acetone powder prepared from axenic mycelia (Table 6). Changes in the relative activity towards D-mannitol and D-arabitol also occurred during storage of mycelial extracts on ice (Table 2). These results suggest the presence of at least three different $\mathrm{NAD}^{+}$-dependent enzymes, specific for D-mannitol, D-arabitol and D-glucitol respectively. The $\mathrm{NAD}^{+}$-dependent xylitol dehydrogenase was shown to be distinct from the above three by its response to DTT. Thus, addition of DTT to extracts stabilized the NAD ${ }^{+}$-dependent xylitol dehydrogenase activity during storage on ice, but did not prevent the rapid loss of D-mannitol or D-arabitol activities (data not presented); furthermore, the stimulation of activity by DTT was far greater for xylitol than for the other polyols (Table 3, and other experiments not presented). Therefore, a total of at least four different $\mathrm{NAD}^{+}$dependent polyol dehydrogenases appear to exist in $P$. graminis.

\section{Discussion}

This investigation provides evidence for at least seven different NAD $(\mathrm{P})^{+}$-dependent polyol oxidizing enzymes (polyol dehydrogenases) in cell-free extracts of $P$. graminis. The enzymes differ in specificity towards polyol substrate and nicotinamide nucleotide coenzyme, sensitivity towards dithiothreitol, stability to heat, cold and storage, and levels of activity in extracts obtained from different biological sources (rust-infected wheat, germinated uredospores, and axenic mycelia). These enzymes catalyse significant rates of oxidation of the following polyols previously identified in $P$. graminis.

D-Mannitol: $\mathrm{NAD}^{+}$, high activity; $\mathrm{NADP}^{+}$, perhaps slight activity in some preparations, and no detectable activity in others. In contrast, substantial mannitoloxidizing activity has been reported with both $\mathrm{NAD}^{+}$ and $\mathrm{NADP}^{+}$in crude extracts of axenic mycelia of the flax rust fungus Melampsora lini (Clancy \& Coffey, 1980), and cell-free preparations of uredospores of the bean rust fungus Uromyces phaseoli (Wynn, 1966).

D-Glucitol (sorbitol): $\mathrm{NAD}^{+}$, low activity; $\mathrm{NADP}^{+}$, high activity. In contrast, $M$. lini possessed no detectable activity with $\mathrm{NAD}^{+}$, and very low activity with $\mathrm{NADP}^{+}$.

D-Arabitol: $\mathrm{NAD}^{+}$, high activity; $\mathrm{NADP}^{+}$, very low activity. This was a similar result to that for $M$. lini, which had high activity with $\mathrm{NAD}^{+}$and no activity with $\mathrm{NADP}^{+}$.

Ribitol: $\mathrm{NAD}^{+}$, no detectable activity; $\mathrm{NADP}^{+}$, moderate activity. $M$. lini showed no detectable activity with either coenzyme.

Xylitol: Moderate to high activity with both $\mathrm{NAD}^{+}$ and $\mathrm{NADP}^{+}$.

Erythritol: $\mathrm{NAD}^{+}$, no activity; $\mathrm{NADP}^{+}$, moderate activity.

Other substrates which supported polyol dehydrogenase activity in the present investigation were L-arabitol and galactitol, neither of which are known to be metabolites of rust fungi. The $\mathrm{NADP}^{+}$-dependent 
activity with $L$-arabitol was particularly interesting due to its lower $K_{\mathrm{m}}$ values than D-glucitol and xylitol. In this regard, wide variation is encountered in the substrate specificities of polyol dehydrogenases studied in other organisms, with some enzymes oxidizing a broad spectrum of substrates, including non-physiological polyols, usually at rates related to configurational similarities, while other enzymes are specific for one polyol with little or no reaction with other polyols (cf. Touster \& Shaw, 1962; Arsenis et al., 1968; Morton et al., 1985). The extent to which the seven different polyol dehydrogenases apparently present in $P$. graminis show cross-specificities can only be determined after their individual purification, although the rapid loss of activity of some of these enzymes after gel filtration may make their purification difficult.

The polyol dehydrogenases detected during this investigation are presumably responsible, at least in part, for metabolism of the polyols which accumulate in mycelia of $P$. graminis. However, the extremely high $K_{\mathrm{m}}$ values for polyols $(\sim 200 \mathrm{mM})$ suggest that the regulation and cellular location of these enzymes in vivo must be important in controlling polyol synthesis and catabolism. A high $K_{\mathrm{m}}$ would allow significant polyol metabolism to occur if the enzymes were present in compartments, as are the intramitochondrial xylitol dehydrogenases of pig liver (Arsenis et al., 1968), for example, and if high local concentrations of substrates accumulated in these compartments. Also, polyols synthesized by other enzyme systems, such as polyol-phosphate dehydrogenases coupled to phosphatases, could produce high local concentrations of free polyols, which could then be catabolized by polyol dehydrogenases. An intramitochondrial $\mathrm{NAD}^{+}$-dependent mannitol-1-phosphate dehydrogenase and a cytoplasmic $\mathrm{NADP}^{+}$-dependent mannitol dehydrogenase have been demonstrated in Aspergillus nidulans by Singh et al. (1988); further research is necessary to determine whether $P$. graminis also possesses such polyol-phosphate-utilizing enzymes.

When considering the role of the polyol dehydrogenases demonstrated in the present investigation in the metabolism of $P$. graminis, it should be noted that NAD $(P)^{+}$-dependent polyol dehydrogenases demonstrated in other fungi and other organisms oxidize free polyols to free aldoses or ketoses; these enzyme reactions are generally freely reversible in vitro (Touster \& Shaw, 1962; Lewis \& Smith, 1967). Furthermore, polyol oxidation can yield a variety of products. For example, oxidation of the 1- or 2-carbon of D-glucitol could produce D-glucose or D-fructose respectively, with other possible products for oxidation of the 5-carbon (L-sorbose) or 6-carbon (L-gulose). Similarly, oxidation of D-mannitol could give two possible products: D-mannose (oxidation of carbons 1 or 6 of D-mannitol) or D-fructose (carbons 2 or 5). In further work, therefore, the precursor-product relationships of these enzymes should be defined, including identification of reaction products of both the forward and reverse reactions. Such an investigation on the possible role of glucitol and mannitol dehydrogenases in the hexitol pathway of $P$. graminis (see below) has recently been completed (McKay, 1990), and will be published separately.

In summary, this investigation has demonstrated that $P$. graminis resembles those fungi which possess a multiplicity of distinct polyol dehydrogenases; e.g. Barnett (1968) obtained evidence for at least eight enzymes differing in electrophoretic mobility and substrate specificity, in extracts of the yeast Torulopsis candida. The existence of multiple polyol dehydrogenases in saprotrophic micro-organisms such as yeasts can be attributed to a need to assimilate a variety of exogenous polyols as alternative carbon sources. However, it is unlikely that ability to utilize a variety of polyols is important for obligatorily parasitic fungi such as $P$. graminis, particularly since concentrations of acyclic polyols in leaves of its wheat (Maclean \& Scott, 1976) and Berberis hosts are extremely low (or absent for hexitols in Berberis leaves or berries; D. J. Maclean, unpublished analyses), in comparison to concentrations of glucose, fructose and sucrose. Presumably, the polyol dehydrogenases are required primarily to organize carbohydrate interconversion and accumulation as part of the normal intermediary metabolism of fungal cells. For example, Maclean (1982) and Manners et al. (1982, 1984, 1988) have demonstrated that D-glucitol and D-mannitol are turned over as intermediates in a 'hexitol pathway' during glucose assimilation by mycelia of $P$. graminis. However, the physiological need for such polyol metabolism in fungi has not yet been satisfactorily explained, as noted by Singh et al. (1988) in an attempt to elucidate the role of D-mannitol in the intermediary metabolism of $A$. nidulans.

\section{References}

Adomako, D., KaYe, M. A. G. \& Lewis, D. H. (1972). Carbohydrate metabolism in Chaetomium globosum. New Phytologist 71, 467-476.

Arsenis, C., Maniatis, T. \& Touster, O. (1968). Intramitochondrial location of the nicotinamide adenine dinucleotide- and nicotinamide adenine dinucleotide phosphate-dependent xylitol dehydrogenases. Journal of Biological Chemistry 244, 4396-4399.

BARNETT, J. A. (1968). The catabolism of acyclic polyols by yeast. Journal of General Microbiology 52, 131-159.

ChIANG, C. \& KNIGHT, S. G. (1961). L-Arabinose metabolism by cellfree extracts of Penicillium chrysogenum. Biochimica et Biophysica Acta 46, 271-278.

Clancy, F. G. \& Coffey, M. D. (1980). Polyol dehydrogenases in the rust fungus, Melampsora lini (Ehrenb.) Lév. Journal of General Microbiology 120, 85-88. 
Duggleby, R. G. (1984). Regression analysis of nonlinear Arrhenius plots: an empirical model and a computer program. Computers in Biology and Medicine 14, 447-455.

Hollmann, S. \& LatTerman, D. (1969). Oxydation von L-Arabit durch eine Polyalkohol-Dehydrogenase aus Hammelsamenblasen. HoppeSeyler's Zeitschrift für Physiologische Chemie 350, 51-56.

ISENBERG, P. \& NIEDERPRUEM, D. J. (1967). Control of erythritol dehydrogenase in Schizophyllum commune. Archiv für Mikrobiologie 56, 22-30.

LEWIS, D. H. \& SMITH, D. C. (1967). Sugar alcohols (polyols) in fungi and green plants. I. Distribution, physiology and metabolism. New Phytologist 66, 143-184.

MaClean, D. J. (1971). Studies on axenic cultures of the wheat stem rust fungus. PhD thesis, University of Queensland.

MACLEAN, D. J. (1974). Cultural and nutritional studies on variant strains of the wheat stem rust fungus. Transactions of the British Mycological Society 62, 333-349.

MaCLEAN, D. J. (1982). Axenic culture and metabolism of rust fungi. In The Rust Fungi, pp. 37-120. Edited by K. J. Scott \& A. K. Chakravorty. London: Academic Press.

Maclean, D. J. \& SCOTT, K. J. (1970). Variant forms of saprophytic mycelium grown from uredospores of Puccinia graminis $\mathrm{f}$. $\mathrm{sp}$. tritici. Journal of General Microbiology 64, 19-27.

MaClean, D. J. \& SCOTT, K. J. (1976). Identification of glucitol (sorbitol) and ribitol in a rust fungus, Puccinia graminis f. sp. tritici. Journal of General Microbiology 97, 83-89.
Manners, J. M., Maclean, D. J. \& SCotT, K. J. (1982). Pathways of glucose assimilation in Puccinia graminis. Journal of General Microbiology 128, 2621-2630.

Manners, J. M., Maclean, D. J. \& Scott, K. J. (1984). Hexitols as major intermediates of glucose assimilation by mycelium of Puccinia graminis. Archives of Microbiology 139, 158-162.

ManNers, J. M., Maclean, D. J. \& SCOTT, K. J. (1988). Metabolism of 2-deoxy-D-glucose by axenically grown mycelia of Puccinia graminis. Experimental Mycology 12, 350-356.

MCKAY, D. B. (1990). Characterization of pathways of carbohydrate assimilation by the wheat stem rust fungus. MSc thesis, University of Queensland.

Morton, N., Dickerson, A. G. \& Hammond, J. B. W. (1985) Mannitol metabolism in Agaricus bisporus: purification and properties of mannitol dehydrogenase. Journal of General Microbiology 131, 2885-2890

Pfyffer, G. E., Pfyffer, B. U. \& RAst, D. M. (1986). The polyol pattern, chemotaxonomy, and phylogeny of the fungi. Sydowia 39, $160-201$.

Singh, M., Scrutton, N. S. \& Scrutton, M. C. (1988). NADPH generation in Aspergillus nidulans: is the mannitol cycle involved? Journal of General Microbiology 134, 643-654.

TOUSTER, O. \& SHAW, D. R. D. (1962). Biochemistry of the acyclic polyols. Physiological Reviews 42, 181-225.

WYNN, W. K. (1966). NAD- and NADP-linked dehydrogenases from bean rust. Plant Physiology 41, xxvi (abstract). 